Purdue University

Purdue e-Pubs

\title{
Instructor and Student Experiences with In-Class Polling Options
}

Julie Mendez

Indiana University-Purdue University Columbus, mendezju@iupuc.edu

Follow this and additional works at: https://docs.lib.purdue.edu/aseeil-insectionconference

Mendez, Julie, "Instructor and Student Experiences with In-Class Polling Options" (2019). ASEE IL-IN Section Conference. 3.

https://docs.lib.purdue.edu/aseeil-insectionconference/2019/assess/3

This document has been made available through Purdue e-Pubs, a service of the Purdue University Libraries. Please contact epubs@purdue.edu for additional information. 


\title{
Instructor and Student Experiences with In-Class Polling Options
}

\begin{abstract}
Active learning pedagogy has been shown to improve student performance in engineering courses. One active learning technique is Peer Instruction, where students individually answer a poll question, and discuss answer choices with a classmate before answering the same question again. There are various options to conduct in-class polling, from low-tech options, such as holding up fingers or a colored card, to more costly digital technologies, such as commercial platforms that require a dedicated device or a student's own mobile device. Previous studies have indicated that the pedagogy matters more than the platform or technology used to conduct polling. However, different platforms allow for different affordances not present in some lowtech options. The high-tech options afford some benefits, including being able to ask questions other than multiple choice, such as open response. The purpose of this study is to gain insight into student preferences and to explore benefits and disadvantages of the different platforms from an instructor prospective. Two groups of students were surveyed: one group who completed a course using Plickers, a low-tech system, and another group from two different courses who used the Top Hat Classroom application on their mobile devices. The survey results indicated that the students had a mostly positive experience with each platform. Benefits and drawbacks from an instructor perspective are described.
\end{abstract}

\section{Introduction}

Active learning has been shown to increase student performance in science, engineering, and math courses [1]. One type of active learning technique is Peer Instruction, which involves the following steps: the instructor presents a multiple-choice conceptual question, students answer the question individually, discuss the answer with other students, and answer again [2], [3]. This method allows for multiple cycles of retrieval practice, which has been shown to be more effective than repeated study [4]. To answer the questions, students could use index cards of different colors or other low-tech methods. Other options involve using a dedicated piece of hardware (clicker), an application on a mobile device, a web browser, or responding via a text message.

Instructors may also want to use in-class polling for activities other than Peer Instruction. Polling software is frequently used to take attendance, provide a discussion prompt, administer quizzes, and solicit anonymous feedback. This paper focuses on two platforms for in-class polling: Plickers [5] and Top Hat Classroom [6]. Plickers was originally developed for K-12 classrooms. Students are given a card with a code, which they use to answer multiple-choice questions with up to four answer choices. Each side of the card is labeled "A", "B", "C", or "D" to indicate different answer choices. To answer the question, students hold up the cards with their answer choice at the top. The instructor uses an application on a mobile device to read the student responses. Top Hat Classroom is a bring-your-own-device classroom response system. Students answer questions by using an application on their mobile devices or via text message. The system provides additional functionality such as the ability for instructors to provide lecture slides and assign work for students to complete outside of class. 
Several studies have shown that Peer Instruction is effective in improving student learning outcomes, particularly related to conceptual understanding of course material [7], [8]. While the pedagogy has been shown to matter more than the technology used [9], different platforms provide different affordances and different potential drawbacks, such as cost or technology requirements. The purposes of this paper are to describe instructor experiences with two different platforms, Plickers and Top Hat Classroom, used in the classroom primarily for Peer Instruction, and to gain student feedback about the two platforms.

\section{Methods}

Plickers cards were used in the Fall 2016 semester in an undergraduate course typically taken in the first semester of the second year in the mechanical engineering curriculum, Thermodynamics. A total of 18 students were enrolled across two sections ( 8 students in section 1 and 10 in section 2). Students used the Plickers cards to answer multiple choice conceptual and problem-based questions. This occurred during 8 weeks of a 15-week course, with more frequent use during the first half of the course. Between 1 and 3 questions were used per week. Plickers cards were used for the same purpose, but less frequently, in the Fall 2015 class, which was the first time this instructor taught the course.

Top Hat Classroom was used in two courses in the Fall 2018 semester: Thermodynamics (17 students) and an undergraduate course typically taken in the first semester of the third year in the mechanical engineering curriculum, Fluid Mechanics (16 students). Students used their mobile devices to answer conceptual multiple-choice questions and to respond to open ended questions. In the Fluid Mechanics course, Top Hat Classroom was used for conceptual multiple-choice questions (Peer Instruction) during 10 weeks of the 15-week course. Typically, 3 or 4 questions were used each week. Additionally, once per week after beginning a new topic, students were asked to respond anonymously to two questions: "What is the most important thing you learned today?" and "What question do you still have?" Fall 2018 was the first time this instructor taught the Fluid Mechanics course. The Thermodynamics class was offered in a hybrid format and had 8 in-person class sessions, approximately once every two weeks. Top Hat Classroom was used for Peer Instruction activities during three of these class sessions. Typically, two questions were used during each class session.

Students from the Fall 2016 Thermodynamics course were sent a two-question survey asking what they liked most and least about using Plickers. Students from the Fall 2018 Thermodynamics and Fluid Mechanics courses were sent a two-question survey asking what they liked most and least about using Top Hat Classroom. The survey was sent to each population one time by email at the end of the Fall 2018 semester. Study data were collected and managed using REDCap electronic data capture tools hosted at Indiana University [10]. REDCap (Research Electronic Data Capture) is a secure, web-based application designed to support data capture for research studies, providing 1) an intuitive interface for validated data entry; 2) audit trails for tracking data manipulation and export procedures; 3) automated export procedures for seamless data downloads to common statistical packages; and 4) procedures for importing data from external sources. Qualitative survey responses were transformed using inductive coding. 


\section{Results}

\section{Student Experiences}

Three responses were received from the survey invitations sent to the 18 students who used Plickers in the Fall 2016 Thermodynamics course (16.7\% response rate). Four responses were received from the survey invitations sent to the 33 students who used Top Hat Classroom in the Fall 2018 Thermodynamics or Fluid Mechanics course (12.1\% response rate).

A summary of the themes that emerged from the survey results are given in Table 1. Each survey response may have contained more than one theme; therefore, the number of results does not necessarily match the number of survey responses. The themes for what students liked most about each platform were nearly identical. For both platforms, students liked the Peer Instruction activities (answer individually, discuss in groups, then answer again), the ability to answer questions anonymously, and how easy the platform was to use. One response about Plickers noted that it worked well for the small class size.

Table 1. Summary of student survey data

\begin{tabular}{|l|l|l|}
\hline Platform & Liked Most & Liked Least \\
\hline Plickers & $\begin{array}{l}\text { Ease of use, Anonymous, } \\
\text { Peer Instruction, Class size }\end{array}$ & Nothing (2), Lost card \\
\hline Top Hat Classroom & $\begin{array}{l}\text { Ease of use (2), Anonymous, } \\
\text { Peer Instruction }\end{array}$ & Nothing (3), Phone charge \\
\hline
\end{tabular}

The most common response to what students liked least about each platform was that they liked everything about it. One student noted that they were supposed to keep their Plickers card in between class sessions and they had lost theirs. One negative attribute noted about Top Hat Classroom was their phone needed to be charged to participate.

\section{Instructor Experiences}

From an instructor perspective using Plickers, one benefit was that relatively little technology was required. The students only needed the paper with the code, and the instructor only needed the mobile application to read the codes. Another benefit was that there was a negligible cost to use Plickers. The instructor smart phone application was free, and there was minimal cost involved with printing the cards for the students. There was no cost for the students. It was also easy to create questions on the fly during class. The main drawback is that Plickers is built only for multiple-choice responses, with a maximum of four answer choices. Occasionally the instructor wished to ask a different type of question, such as open response for feedback. However, the multiple-choice format is adequate for Peer Instruction, and the multiple-choice format may be preferred by instructors of large classes to quickly interpret the responses.

Top Hat Classroom has increased functionality. Multiple types of questions can be used, including multiple choice, click on target, numeric answer, and word answer. Instructors can assign questions outside of class for homework or review, but this feature was not used in the classes in this study. While each student has an account, so that their name is associated with their responses, there is an option within each question for the responses to be anonymous. This 
option was used for open-ended reflection questions ("What is the most important thing you learned today?" and "What question do you still have?") at the end of class. If students are using the application on their devices, they can view the presented question on their devices in addition to wherever the instructor is displaying it in the classroom. There are some potential drawbacks. Depending on the institutional agreement with Top Hat, students may be required to pay a fee to use the service. Answering the questions require students to have a mobile device or have access to a computer in the classroom.

\section{Discussion}

In response to the student issues raised in the survey responses, the instructor observed that students typically had their Plickers cards with them during class. There were a few occasions were a student forgot or misplaced their card; in these cases, the student was given an extra card to use temporarily. The Plickers cards were not used for attendance or for graded activities, so it was not critical that each student have their originally assigned card number. While using Top Hat Classroom, the instructor did not observe any students with uncharged cell phones. No technical issues were observed with Top Hat that led to students not being able to participate.

In each of the classes, nearly all students who were present engaged in the activities. For the class using Plickers, each student had to hold up their card, and in this small class (10 or fewer in each section) it was obvious to the instructor who was participating in each question. In the classes that used Top Hat, since each student answered on their own device, it was less obvious to the instructor who was participating in each question. Since student responses are recorded, it is possible to view from the instructor dashboard who answered each question. Since the purpose of the activities was not for attendance or for a grade, but rather to engage students in discussion, the instructor rarely viewed the details for each question. During the small group discussion of each question, since each class was small (17 students or fewer), the instructor was able to walk around the room to listen to discussions and get an idea of who was participating. From instructor observations, all students participated in the peer discussions.

The two classes that used Top Hat were one sophomore-level and one junior-level course. No significant differences in the classroom were observed between the two classes in terms of their attitudes or use of the platform. From instructor observation, students in each class were equally as likely to participate by answering the question using their devices and by participating in the small group discussions.

The responses to the survey indicated that the students had a largely positive experience with both platforms, but a few concerns were raised. Some ideas to improve the classroom experience based on the survey responses are to bring extra Plickers cards to class. In classrooms using Top Hat Classroom, one could try to schedule the class in a room with computers or with many outlets to charge cell phones. The instructor could announce to students ahead of time if mobile devices will be needed each class period or only on certain days. This may allow students to charge their phones before class or bring a charger with them. An instructor may also consider bringing extra phone chargers and making them available for use during class.

One limitation of this study is the low survey response rates $(16.7 \%$ for the Plickers survey and $12.1 \%$ for the Top Hat Classroom survey). This means that the responses that were received may 
not be representative of each of the classes. Additionally, this study was limited to one instructor's experience in two different courses. Students may not necessarily respond in the same way in different courses or to different instructors.

\section{Conclusion}

One group of students who used Plickers and two groups of students who used Top Hat Classroom were surveyed about what they liked the most and least about the platform they used. The survey results indicated that the students had mostly positive experiences with each platform, listing Peer Instruction activities, ease of use, and being able to answer anonymously as things they liked. For Plickers, an issue was losing the card between class sessions. For Top Hat Classroom, it was necessary for students to have charged mobile devices. The instructor experiences with both platforms was positive. Some suggestions for improvement to the student experience are to bring extra Plickers cards to class, and, if students are required to use mobile devices or a web browser, schedule the class in a room with computers and/or outlets for charging their devices.

\section{References}

[1] S. Freeman, S. L. Eddy, M. McDonough, M. K. Smith, N. Okoroafor, H. Jordt, and M. P. Wenderoth, "Active learning increases student performance in science, engineering, and mathematics," Proceedings of the National Academy of Sciences, vol. 111, no. 23, pp. 8410-8415, Jun. 2014.

[2] C. H. Crouch and E. Mazur, "Peer Instruction: Ten years of experience and results," American Journal of Physics, vol. 69, no. 9, pp. 970-977, Aug. 2001.

[3] J. A. Schell and A. C. Butler, "Insights From the Science of Learning Can Inform Evidence-Based Implementation of Peer Instruction," Frontiers in Education, vol. 3, p. 33 May 2018.

[4] H. L. Roediger and A. C. Butler, "The critical role of retrieval practice in long-term retention," Trends in Cognitive Sciences, vol. 15, no. 1, pp. 20-27, Jan. 2011.

[5] "Plickers." [Online]. Available: https://get.plickers.com/. [Accessed: 15-Jan-2019].

[6] “Top Hat Classroom,” Top Hat. [Online]. Available: https://tophat.com/classroom/. [Accessed: 15-Jan-2019].

[7] R. N. Cortright, H. L. Collins, and S. E. DiCarlo, "Peer instruction enhanced meaningful learning: ability to solve novel problems," Advances in Physiology Education, vol. 29, no. 2, pp. 107-111, Jun. 2005.

[8] M. Lorenzo, C. H. Crouch, and E. Mazur, "Reducing the gender gap in the physics classroom," American Journal of Physics, vol. 74, no. 2, pp. 118-122, Jan. 2006.

[9] K. Gray and D. N. Steer, "Personal Response Systems and Learning: It Is the Pedagogy That Matters, Not the Technology," Journal of College Science Teaching, vol. 41, no. 5, pp. 80-88, Jun. 2012.

[10] P. A. Harris, R. Taylor, R. Thielke, J. Payne, N. Gonzalez, and J. G. Conde, "Research electronic data capture (REDCap) - A metadata-driven methodology and workflow process for providing translational research informatics support," Journal of Biomedical Informatics, vol. 42, no. 2, pp. 377-381, Apr. 2009. 